\title{
PENERAPAN MODEL PEMBELAJARAN KONTRUKTIVISME UNTUK MENINGKATKAN KEMAMPUAN MENULIS TEKS DRAMA PADA SISWA KELAS XI IPS MA SYAMSUL HUDA TEGALLINGGAH
}

\author{
Oleh : \\ KIKI AULIA RIZKI, S.Pd.,M.Pd. \\ e-mail: kiki.aulia03@yahoo.co.id/kaulia018@gmail.com
}

\begin{abstract}
ABSTRAK
Penelitian Tindakan Kelas (PTK) ini bertujuan (1) mendeskripsikan peningkatan kemampuan siswa dalam menulis teks drama melalui penerapan model pembelajaran kontruktivisme kelas XI IPS MA Syamsul Huda Tegallinggah, dan (2) mendeskripsikan respons siswa kelas XI IPS MA Syamsul Huda Tegallinggah terhadap penerapan model pembelajaran kontruktivisme. Subjek dalam penelitian ini adalah guru dan siswa kelas XI IPS MA Syamsul Huda Tegallinggah. Objek penelitian ini adalah peningkatan hasil, dan respons siswa dalam penerapan model pembelajaran Kontruktivisme dalam pembelajaran menulis teks drama. Metode pengumpulan data yang digunakan dalam penelitian ini adalah tes, dan anggket atau kuesioner. Data yang didapatkan dianalisis dengan teknik deskriptif-kualitatif dan deskriptif-kuantitatif. Hasil penelitian ini menunjukkan bahwa, (1) penerapan model pembelajaran kontruktivisme dapat meningkatkan keterampilan menulis teks drama siswa. Hal ini dapat dilihat dalam perbandingan skor rata-rata klasikal, yakni pada pratindakan skor rata-rata klasikal 68.33 (cukup), siklus I memperoleh skor rata-rata klasikal 76,39 (baik), sedangkan pada siklus II nilai rata-rata klasikal siswa menjadi 85,65 (baik); (3) siswa memberikan respons sangat positif terhadap penerapan model pembelajaran kontruktivisme dalam pembelajaran menulis teks drama. Dari hasil yang telah dicapai, bahwa model pembelajaran kontruktivisme perlu dipertimbangkan sebagai upaya untuk mengoptimalkan proses dan hasil belajar bahasa dan sastra.
\end{abstract}

Kata kunci : Kontruktivisme, menulis, teks drama

\begin{abstract}
This classroom action research is aimed at (1) describing the improvement of students' ability in writing drama text through the implementation of class XI IPS MA Syamsul Huda Tegallinggah, and (2) to describe the response of grade XI IPS students MA Syamsul Huda Tegallinggah to the application of learning model kontruktivisme. Subjects in this study were teachers and students of class XI IPS MA Syamsul Huda Tegallinggah. The object of this research is improvement of result, and student's


response in applying of model of Kontruktivisme learning in writing drama text writing. Data collection method used in this research is test, kuesioner. The data obtained were analyzed by descriptive-qualitative and descriptive-quantitative techniques. The results of this study indicate that, (1) the implementation of the learning model of contructivism can improve the skills of writing drama students. This can be seen in the comparison of classical average scores, ie on the pratindakan classical average score of 68.33 (enough), cycle I obtained a classical average score of 76.39 (good), whereas in cycle II the average value of classical students to be 85.65 (good); (3) students respond very positively to the implementation of the learning model of contructivism in learning to write drama text. From the results achieved, that the model of learning kontruktivisme need to be considered as an effort to optimize the process and the results of learning language and literature.

Keywords : Constructivism, writing, drama text

\section{PENDAHULUAN}

Mutu pendidikan sering diartikan sebagai karakteristik pendidikan yang sesuai dengan kriteria tertentu untuk memenuhi kepuasan pengguna (user) pendidikan, yakni peserta didik, orang tua, serta pihak-pihak berkepentingan lainnya. Guna menjaga mutu proses tersebut, diperlukan adanya quality control yang mengawasi jalannya proses dan segala komponen pendukungnya. Salah satu bentuk komponen dasar untuk meningkatkan kualitas pendidikan yang memiliki kontribusi tinggi bagi pembangunan pendidikan adalah kurikulum. Dalam hal ini, pemerintah telah melakukan berbagai upaya guna meningkatkan kualitas pendidikan berdasarkan komponen fundamental tersebut.

Dilihat dari perspektif yang mendalam, pendidikan dewasa ini bukan hanya untuk memenuhi target kurikulum semata, namun menuntut adanya pemahaman tinggi peserta didik. Pemahaman yang dimaksudkan, bukanlah pemahaman dalam arti sempit, yaitu menghafal materi pelajaran, tetapi pemahaman dalam arti luas. Pemahaman yang dimaksud, lebih cenderung menekankan pada kegiatan proses pembelajaran yang meliputi menemukan konsep, mencari, memproduksi, dan lain sebagainya serta peserta didik dituntut untuk dapat mengaplikasikannya dalam kehidupan sehari-hari. Namun sayangnya, praktik pembelajaran yang demikian masih belum diterapkan secara keseluruhan, sehingga tujuan dan hasil pendidikan belum sesuai dengan yang diharapkan. 
Secara menghusus, tujuan dan hasil pendidikan berupa produk kerap menjadi kendala oleh siswa sebab produk yang dihasilkan siswa, tidak atau kurang memenuhi kriteria tujuan pendidikan yang diharapkan. Produk berupa teks dalam pembelajaran bahasa Indonesia, misalnya terdapat berbagai jenis teks yang perlu dikuasai dan diproduksi oleh siswa pada jenjang kelas XI Sekolah Menengah Atas atau SMA. Salah satunya adalah teks drama.

Menulis sebagai proses berpikir memiliki arti bahwa sebelum, saat, atau setelah menuangkan gagasan dan perasaan secara tertulis diperlukan keterlibatan proses berpikir. Melalui proses berpikir, gagasan yang dituangkan ke dalam kalimat atau paragraf dapat dianalisis kelogisannya. Dengan demikian, menulis dan proses berpikir berkaitan erat dalam menghasilkan tulisan yang runtut. Tulisan yang runtut merupakan manifestasi dari keterlibatan proses berpikir. Proses berpikir sangat menentukan terciptanya sebuah tulisan yang berkualitas. Salah satu substansi retorik menulis adalah penalaran yang baik, seperti dikatakan Syafi'ie (dalam Arini dkk, 2007: 183). Hal tersebut berarti bahwa penulis harus mampu melibatkan proses berpikir rasional, kritis, dan kreatif. Pada saat menulis, siswa dituntut berpikir untuk menuangkan gagasannya secara tertulis berdasarkan skemata, pengetahuan, dan pengalaman yang dimilikinya. Dalam proses tersebut diperlukan kesungguhan menyusun, menata, serta mempertimbangkan secara kritis, dan menata ulang gagasan yang dicurahkan. Hal tersebut sangat diperlukan agar tulisan yang dihasilkan dapat dipahami dengan baik oleh orang lain.

Menulis kreatif teks drama merupakan salah satu keterampilan bidang apresiasi sastra yang harus dikuasai oleh siswa SMA/MA. Di dalam kurikulum 2013 Bahasa Indonesia, materi menulis kreatif teks drama terdapat pada pembelajaran yang diajarkan di kelas XI yakni mengungkapkan pikiran dan perasaan melalui kegiatan menulis teks drama. Akan tetapi, pada kenyataannya pembelajaran menulis teks drama di sekolah masih banyak mengalami kendala misalnya kurang dalam menemukan ide dan kurang dalam menyusun kalimat.

Pembelajaran menulis teks drama di MA dilakukan dengan tujuan, meningkatkan kemampuan siswa dalam mengapresiasi karya sastra. Hal itu berkaitan erat dengan latihan mempertajam perasaan, penalaran, dan daya khayal, serta kepekaan 
terhadap masyarakat, budaya, dan lingkungan hidup. Seperti yang diungkapakan Wahono dan Rusmiyanto (2007) bahwa drama adalah potret kehidupan yang diungkapkan oleh pengarang dalam sebuah teks. Kesan-kesan dapat diperoleh melalui pengalaman dan lingkungan. Oleh karena itu, anggapan bahwa menulis teks drama sebagai aktvitas yang sulit,

Mata pelajaran bahasa Indonesia merupakan salah satu mata pelajaran yang banyak menuntut guru untuk pandai-pandai memilih model pembelajaran. Pemilihan model pembelajaran yang tepat perlu diupayakan guru untuk memudahkan proses terbentuknya pengetahuan pada siswa, namun guru juga harus memperhatikan apakah model pembelajaran yang digunakan itu penerapannya sudah efektif dan efisien. Dengan demikian, proses pembelajaran akan lebih variatif, inovatif, dan kontruktif dalam upaya meningkatkan aktivitas kreativitas siswa.

Penerapan model-model pembelajaran inovatif akan dapat meningkatkan kemampuan dan keterampilan siswa secara maksimal sehingga pembelajaran menjadi lebih inovatif demi meningkatkan mutu pendidikan. Hal tersebut sesuai temuan berbagai penelitian yang dilaksanakan oleh pakar pendidikan, pemerhati pendidikan, dan praktisi pendidikan bahwa penggunaan model pembelajaran yang tepat dapat membangkitkan dominasi siswa dalam belajar, seperti aktif, kreatif dan inovatif serta dapat menimbulkan suasana yang menyenangkan. Kegiatan seperti ini dapat meningkatkan hasil belajar siswa.

Dengan demikian, para pengajar sangat penting untuk mempelajari dan menambah wawasan tentang model pembelajaran yang telah diketahui. Oleh karena, dengan menguasai beberapa model pembelajaran, maka seorang guru akan merasakan adanya kemudahan di dalam pelaksanaan pembelajaran di kelas, sehingga tujuan pembelajaran yang hendak dicapai dalam proses pembelajaran dapat tercapai dan tuntas sesuai yang diharapkan.

Apabila permasalahan tersebut tidak dicarikan solusinya, dikhawatirkan tujuan pembelajaran menulis khususnya menulis teks drama tidak akan tercapai dengan baik dan akan berimplikasi pada mutu lulusan yang rendah. Menyikapi fenomena tentang rendahnya kemampuan menulis peserta didik, pendidik sebagai fasilitator perlulah 
merencanakan suatu bentuk pembelajaran yang dapat dijadikan sebagai solusi atas permasalahan tersebut sehingga pembelajaran menjadi lebih efektif dan efisien. Salah satu model pembelajaran yang dapat digunakan untuk lebih mengaktifkan siswa dan membantu siswa dalam proses pembelajaran terkait dengan permasalahan tersebut adalah penggunaan model pembelajaran kontruktivisme.

Model pembelajaran kontruktivisme merupakan sebuah teori tentang proses orang belajar. Di dalam konteks pembelajaran, siswa dipandang sebagai individu yang aktif membangun pemahamannya sendiri dan pengetahuan dunia sekitarnya dengan mengalami sendiri dan merefleksikan pengalaman tersebut. Pembelajaran kontruktivisme menekankan pentingnya siswa membangun sendiri pengetahuan mereka lewat keterlibatan aktif proses belajar mengajar (Suparno dalam Nurjaya, 2013: 73). Dengan adanya model ini, diharapkan siswa lebih semangat dan bergairah dalam belajar menulis teks drama.

Keyakinan akan keunggulan model pembelajaran kontruktivisme adalah pembelajaran kontruktivisme erat hubungannya dengan pencapaian kemampuan yang maksimal dari setiap siswa dalam menulis teks drama. Hal ini didukung hasil penelitian Dini Nursari (2012) yang berjudul "Pembelajaran Menulis Puisi dengan Menggunakan Metode Konstruktivisme di Kelas V". Hasil belajar siswa dengan model pembelajaran kontruktivisme meningkat lebih baik dari pada pembelajaran konvensional.

Dengan mempertimbangkan karakteristik peserta didik pada kelas XI MA Syamsul Huda Tegallinggah, demi memperkecil kesenjangan yang terjadi, akhirnya diputuskan untuk melakukan penelitian dengan judul Penerapan Model Pembelajaran Kontruktivisme untuk Meningkatkan Kemampuan Menulis Teks Drama pada Siswa Kelas XI MA Syamsul Huda Tegallinggah.

\section{METODE}

Penelitian ini menggunakan rancangan penelitian tindakan kelas yang dilakukan dalam dua siklus. Dalam pe-nelitian tindakan kelas ini dilaksanakan sebanyak dua siklus dengan masing-masing siklus terdiri atas empat tahapan, yaitu: (1) perencanaan, (2) 
tindakan, (3) observasi/evaluasi, dan (4) refleksi. Subjek dalam penelitian ini adalah siswa kelas XI, serta guru yang mengajar di kelas XI. Objek penelitian ini adalah peningkatan keterampilan menulis teks drama dengan peneraapan model pembelajaran kontruktivisme, dan respons siswa terhadap penerapan model pembelajaran kontruktivisme.

Metode pengumpulan data yang digunakan dalam penelitian ini adalah metode tes, dan metode angket/kuesioner. Metode tes digunakan untuk mengetahui kemampuan siswa dalam menulis teks drama. Metode ang-ket/kuesioner digunakan untuk mengetahui respons siswa terhadap penerapan model pembelajaran kontruktivisme dalam pembelajaran menulis teks drama. Penelitian ini menggunakan instrumen sebagai alat untuk mendukung penggunaan metode tersebut. Instrumen yang digunakan dalam penelitian ini adalah lembar angket/kuesioner respons siswa.

Setelah data terkumpul, dianalisis dengan menggunakan teknik deskriptif kuantitatif dan deskriptif kualitatif. Teknik deskriptif kualitatif digunakan untuk menganalisis data dengan cara meng-interpretasikan data yang diperoleh dengan menggunakan kata-kata. Teknik deskriptif kuantitatif digunakan untuk menganalisis data dengan cara meng-interpretasikan data yang diperoleh dengan menggunakan angka-angka. Dalam penelitian ini, data hasil menulis teks drama dianalisis menggunakan analisis data deskripstif kualitatif dan kuantitatif. Data respons siswa dianalisis dengan teknik deskriptif kuantitatif dan kualitatif.

Kriteria keberhasilan yang digunakan sebagai patokan dalam mengakhiri penelitian ini adalah sebagai berikut. Pertama, standar kemampuan menulis teks drama adalah 70\% siswa mampu memeroleh nilai 70-100, yaitu sesuai dengan standar ketuntasan minimal pelajaran bahasa Indonesia yang ditetapkan di MA Syamsul Huda Tegallinggah

\section{HASIL DAN PEMBAHASAN}

Ada dua temuan penting pada penelitian ini, yaitu (1) penerapan model pembelajaran kontruktivisme untuk meningkatkan kemampuan menulis teks drama, dan (rata-rata skor 85,65), dan (2) respons siswa terhadap penerapan model pembelajaran kontruktivisme dalam pembelajaran menulis teks drama tergolong sangat positif. 
Dalam penelitian ini ditemukan bahwa penerapan model pembelajaran kontruktivisme membantu meningkatkan kemampuan menulis teks drama siswa kelas XI MA Syamsul Huda Tegallinggah. Jika dibandingkan dengan hasil yang diperoleh sebelum menggunakan model pembelajaran kontruktivisme terjadi peningkatan hingga memenuhi KKM yang telah ditentukan. Pernyataan ini diperkuat dari hasil tes yang diperoeh siswa pada pelaksanaan tindakan siklus II.

Tabel 1. Perbandingan antara skor rata-rata kelas sebelum dilakukan tindakan, pada siklus I, dan pada siklus II.

\begin{tabular}{l|c|}
\hline Pelaksanaan & Skor rata-rata kelas \\
\hline Pratindakan & 68,33 \\
Siklus I & 76,39 \\
Siklus II & 85,65 \\
\hline
\end{tabular}

Peningkatan skor ini membuktikan bahwa penerapan pembelajaran kontruktivisme dapat meningkatkan kemampuan mengemukakan pendapat. Hal ini sesuai dengan yang diungkapkan oleh Suparno dalam Nurjaya (2013: 73) yang menyatakan pembelajaran kontruktivisme merupakan sebuah teori tentang proses orang belajar. Di dalam konteks pembelajaran, siswa dipandang sebagai individu yang aktif membangun pemahamannya sendiri dan pengetahuan dunia sekitarnya dengan mengalami sendiri dan merefleksikan pengalaman tersebut. Pembelajaran kontruktivisme menekankan pentingnya siswa membangun sendiri pengetahuan mereka lewat keterlibatan aktif proses belajar mengajar.

Pemilihan model pembelajaran kontruktivisme sangatlah tepat, karena dalam pembelajaran menulis teks drama setiap siswa memiliki kesempatan untuk menyampaikan pendapatnya terhadap suatu topik. Tidak ada siswa yang hanya mendengarkan pendapat teman atau hanya menyerahkan tugas menulis teks drama 
kepada rekan yang dianggap pintar. Semua siswa mendapat giliran untuk mengeluarkan ide, Pernyataan tersebut didukung oleh Lie(2008: 62) menyatakan bahwa siswa dituntut untuk memiliki tanggungjawab dan aktif dalam setiap kegiatan pembelajaran.

Temuan di atas sejalan dengan temuan pada penelitian yang dilakukan oleh Dini Nursari (2012) yang berjudul "Pembelajaran Menulis Puisi dengan Menggunakan Metode Konstruktivisme di Kelas V". Hasil belajar siswa dengan model pembelajaran kontruktivisme meningkat lebih baik dari pada pembelajaran konvensional.

Faktor lainnya adalah pemberian bimbingan dan penghargaan oleh guru dapat mendorong siswa menjadi lebih aktif. Guru memiliki peranan yang amat penting dalam keseluruhan proses pembelajaran. Upaya guru dalam membimbing siswa harus didasari dengan kesabaran. Guru harus tetap menghargai usaha siswa baik yang belum berhasil maupun yang sudah berhasil. Bimbingan yang diberikan guru dalam menulis teks drama dapat mempermudah siswa dalam memahami pelajaran yang diberikan. Kesulitan yang dialami siswa dalam pembelajaran dapat segera teratasi karena bimbingan yang diberikan oleh guru. Guru mampu memotivasi siswanya untuk belajar. Pernyataan tersebut didukung oleh Djamarah (2002:182) menyatakan, "Motivasi memegang peranan penting dalam belajar. Seorang siswa tidak akan dapat belajar dengan baik dan tekun jika tidak ada motivasi dalam dirinya. Bahkan tanpa motivasi, seorang siswa tidak akan melakukan kegiatan belajar". Maka dari itu, guru perlu memberikan motivasi kepada siswa selama proses belajar berlangsung. Selain itu, guru juga memegang peranan penting dalam memengaruhi peningkatan hasil belajar siswa. Motivasi belajar oleh guru dalam melaksanakan pembelajaran di kelas dapat meningkatkan hasil belajar siswa, khususnya dalam pembelajaran menulis teks drama. Motivasi memiliki manfaat untuk membangkitkan, meningkatkan, dan memelihara semangat siswa untuk belajar sampai berhasil. Dalam penelitian ini, guru mulai memberikan motivasi kepada siswa saat siswa mengalami hambatan. Motivasi yang diberikan guru, tidak di depan kelas saja, tetapi secara langsung mendekati dan berkomunikasi dengan siswa. Dari pelaksanaan langkah-langkah yang diterapkan, guru telah berupaya semaksimal mungkin untuk mengaktifkan siswa dalam kegiatan pembelajaran. 
Temuan kedua, yaitu siswa menjadi sangat senang dan aktif mengikuti pembelajaran menulis teks drama. Ini merupakan temuan penting terakhir dalam penelitian ini. Hal tersebut dapat dilihat dari rata-rata respons yang diberikan oleh siswa dalam pembelajaran ini. Sebagian besar siswa memberikan respons yang sangat positif terhadap tindakan yang dilakukan dalam pembelajaran. Pada siklus I nilai rata-rata respons siswa adalah 21,8 (kategori sangat setuju), kemudian nilai rata-rata respons siswa meningkat menjadi 22,8. (sangat sangat setuju) pada siklus II. Siswa merasa senang melakukan kegiatan pembelajaran ini karena divariasikan dengan penerapan model pembelajaran kontruktivisme. Apabila individu berada dalam situasi yang betulbetul bebas dari berbagai bentuk tekanan atau hambatan yang dapat mengganggu sikapnya, dapat diharapkan bahwa bentuk-bentuk perilaku yang ditampakkannya merupakan ekspresi sikap yang sebenarnya.

Temuan kedua ini didukung oleh respons yang diberikan siswa terhadap penerapan model pembelajaran kontruktivisme pada angket respons, yaitu sebagian besar siswa merasa tertarik, lebih memahami, dan lebih mudah dan berani mengemukakan pendapat pada teman dengan model kontruktivisme. Pernyataan ini sejalan dengan pendapat Lie(2008: 62) mengenai kelebihan model pembelajaran yaitu memberikan kesempatan kepada siswa untuk menciptakan kreativitas dalam melakukan kegiatan menulis teks drama dengan teman sekelompoknya dan membiasakan siswa untuk bersikap terbuka terhadap teman.

Sama halnya dengan pernyataan angket selanjutnya, yaitu sebagian besar siswa merasa tidak terbebani dan lebih kreatif dalam menulis teks drama dengan model pembelajaran kontruktivisme. Pernyataan tersebut didukung oleh pendapat Lie (2000: 60) yang menyatakan bahwa model pembelajaran kontruktivisme mampu memberikan kesempatan kepada siswa untuk menciptakan kreativitas dalam melakukan kegiatan menulis teks drama dengan teman sekelompoknya dan membiasakan siswa untuk bersikap terbuka terhadap teman. Selain itu, dalam penerapan model pembelajaran kontruktivisme, sekitar sebagian besar siswa merasa lebih mendapatkan ide-ide dari diskusi yang dilakukan dan lebih percaya diri, tidak canggung dalam mengemukakan pendapat pada teman terutama pada kelompok lainnya dengan model pembelajaran kontruktivisme . Lie (2000:62) menyatakan bahwa model pembelajaran kontruktivisme 
melatih siswa untuk terbiasa berpikir, menuangkan ide/gagasan dan berani menjelaskan serta membagi hasil diskusi kelompok kekelompok lainnya.

Jadi, penerapan model pembelajaran kontruktivisme dapat meningkatkan kemampuan menulis teks drama siswa. Hal ini dapat dilihat dari peningkatan hasil tes keterampilan berdiskusi pada siklus II dibandingkan dengan hasil tes pada siklus I dan peningkatan hasil belajar dapat pula dilihat dari perbandingan nilai awal siswa sebelum melaksanakan tindakan terhadap siklus I. Aktivitas belajar siswa juga mengalami peningkatan yang terlihat pada siklus I dan siklus II. Untuk mengatasi beragam permasalahan yang ditemukan oleh guru ataupun siswa dalam pembelajaran menulis teks drama, guru dapat mengaplikasikan pembelajaran dengan model pembelajaran kontruktivisme yang dapat dijadikan sebagai salah satu alternatif dalam upaya meningkatkan kemampuan menulis teks drama siswa.

\section{SIMPULAN DAN SARAN}

Berdasarkan pembahasan di atas, ada beberapa hal yang menjadi simpulan dalam penelitian ini. Pertama, penerapan model pembelajaran kontruktivisme dapat meningkatkan kemampuan menulis teks drama siswa di kelas XI MA Syamsul Huda . Hal tersebut dapat dilihat dari adanya peningkatan hasil dari sebelum dilakukan penelitian. Nilai rata-rata siswa sebelum dilakukan tindakan adalah 68,33 (cukup). Nilai rata-rata siswa pada siklus I adalah 76,39 (cukup) dan nilai rata-rata pada siklus II adalah 85,65 (baik). Peningkatan yang terjadi sebesar 17,32. kedua, penerapan model pembelajaran kontruktivisme dapat meningkatkan kemampuan menulis teks drama mendapat respons sangat positif dari siswa di kelas XI MA Syamsul Huda Tegallinggah. Siswa mengaku senang terhadap penerapan model pembelajaran kontruktivisme dalam pembelajaran menulis teks drama. Hal tersebut dapat dilihat dari jawaban kuesioner siswa yang menunjukkan sikap positif dan sangat positif.

Berdasarkan temuan-temuan dalam penelitian ini, peneliti dapat menyampaikan beberapa saran sebagai berikut. (1) Peneliti menyarankan agar siswa menerapkan model pembelajaran ini dalam mencapai peningkatan hasil belajar. (2) Kepada peneliti lain, paparan yang terdapat dalam penelitian ini dapat dijadikan bahan dalam meneliti masalah lain yang sejenis dengan penelitian ini. Karena, peneliti yakin bahwa dalam 
penelitian ini masih ada hal yang belum dibahas dan terselesaikan, oleh sebab itu peneliti lain bisa menemukan tindakan lebih lanjut dalam mengatasinya,

\section{DAFTAR PUSTAKA}

Arini, W. 2007. Mengefektifkan Pembelajaran Menulis Deskripsi dengan Memanfaatkan Benda-benda Lingkungan Kelas sebagai Sumber Belajar Siswa Kelas IV SDN 3 Kampung Anyar Singaraja. Jurnal. JPP, Lembaga Penelitian Undiksha Singaraja.

Djamarah dan Zain. 2002. Strategi Belajar Mengajar. Jakarta: Rineka Cipta.

Lie, Anita. 2000. Cooperatif Learning. Jakarta: PT. Gramedia Sarana Indonesia.

------. 2008. Cooperative Learning: Mempraktikkan Cooperative Learning di RuangRuang Kelas. Jakarta: PT Grasindo.

Nurjaya, I Gede. 2013. Metode Pembelajaran Bahasa dan Sastra Indonesia. Singaraja: Universitas Pendidikan Ganesha.

Nursari, Dini. (2012). Pembelajaran Menulis Puisi dengan Menggunakan Metode Kontruktivisme di Kelas V. Tesis. (tidak diterbitkan). Bandung: (STKIP) Siliwangi. 